\title{
Different Approaches to the Development of Online Learning in Higher Education
}

\section{Diferentes enfoques para el desarrollo del aprendizaje en línea en la educación superior}

\author{
Iurii V. Kornilov* \\ M.K. Ammosov North-Eastern Federal University, Yakutsk, Russia \\ ORCID: https://orcid.org/0000-0002-5801-2616 \\ Dmitriy A. Danilov \\ M.K. Ammosov North-Eastern Federal University, Yakutsk, Russia \\ ORCID: https://orcid.org/0000-0002-3590-1031 \\ Alla G. Kornilova \\ M.K. Ammosov North-Eastern Federal University, Yakutsk, Russia \\ ORCID: https://orcid.org/0000-0001-6790-3085 \\ Aleksei I. Golikov \\ M.K. Ammosov North-Eastern Federal University, Yakutsk, Russia \\ ORCID: https://orcid.org/0000-0003-4112-4045 \\ Ilya B. Gosudarev \\ ITMO University, St. Petersburg, Russia \\ ORCID: https://orcid.org/0000-0003-4236-5991
}

Received 07-12-20 Revised 07-30-20 Accepted 08-29-20 On line 09-15-20

*Correspondence

Email: iuriikornilov@yandex.ru
Cite as:

Kornilov, Iu.P., Danilov, D.A., Kornilova, A.G., Golikov, A.I., \& Gosudarev, I.B. (2020). Different Approaches to the Development of Online Learning in Higher Education. Propósitos y Representaciones, 8 (SPE3), e706. Doi: http://dx.doi.org/10.20511/pyr2020.v8nSPE3.706 


\section{Summary}

The relevance of the study is substantiated by the intensive transition of the educational process to the digital environment. In this context, methods and principles of teaching, which are necessary to meet the society needs in modern education, are changing and developing. The authors reveal the issue of the global economy transformation, focusing on digital environments (digitalization). It is highlighted that digitalization contributes to the increasing demand for personnel and the necessity to improve the education system. The analysis of the theoretical features of online education is conducted, methods of its organization are identified, and modern requirements for teaching in higher education are determined. The key concepts that are the basis for the study are clarified. Approaches to the classification of online course formats and their other essential features are generalized. The authors introduce the classification of online learning in terms of time (synchronous, asynchronous) and the classification according to the degree of the educational process integration with online technologies. Additionally, the character of participants' interaction (web support, blended learning, and fully online learning) is generalized. A review of online courses models by the format of participants' interaction is carried out (model of online repository courses, xMOOC, cMOOC, hMOOC, ahMOOC, SPOC). The processes of online learning implementation, including e-learning and distance learning technologies in higher education have been revealed. The experience of the development of the first online courses at M. K. Ammosov North-Eastern Federal University is described. As a part of the study, the main approaches to the development of online learning in higher education are identified. The authors of the study focus on the work of the advanced training courses for the academic staff as the opportunity for professional competencies development in the context of online education.

Keywords: Online Learning, Online Courses, SPOC, Higher Education, Approaches to the Online Learning Development.

\section{Resumen}

La relevancia del estudio se fundamenta en la transición intensiva del proceso educativo al entorno digital. En este contexto, los métodos y principios de enseñanza, que son necesarios para satisfacer las necesidades de la sociedad en la educación moderna, están cambiando y desarrollándose. Los autores revelan el tema de la transformación de la economía global, centrándose en entornos digitales (digitalización). Se destaca que la digitalización contribuye a la creciente demanda de personal y la necesidad de mejorar el sistema educativo. Se realiza el análisis de las características teóricas de la educación en línea, se identifican los métodos de su organización y se determinan los requisitos modernos para la enseñanza en la educación superior. Se aclaran los conceptos clave que son la base del estudio. Los enfoques para la clasificación de los formatos de cursos en línea y sus otras características esenciales se generalizan. Los autores introducen la clasificación del aprendizaje en línea en términos de tiempo (síncrono, asíncrono) y la clasificación según el grado de integración del proceso educativo con las tecnologías en línea. Además, el carácter de la interacción de los participantes (soporte web, aprendizaje combinado y aprendizaje totalmente en línea) se generaliza. Se realiza una revisión de los modelos de cursos en línea por el formato de interacción de los participantes (modelo de cursos de repositorio en línea, xMOOC, cMOOC, hMOOC, ahMOOC, SPOC). Se han revelado los procesos de implementación del aprendizaje en línea, incluidas las tecnologías de aprendizaje electrónico y aprendizaje a distancia en la educación superior. Se describe la experiencia del desarrollo de los primeros cursos en línea en Universidad Federal del Nordeste M. K. Ammosov. Como parte del estudio, se identifican los principales enfoques para el desarrollo del aprendizaje en línea en la educación superior. Los autores del estudio se centran en el trabajo de los cursos de capacitación avanzada para el personal académico como la oportunidad para el desarrollo de competencias profesionales en el contexto de la educación en línea.

Palabras Clave: Aprendizaje en línea, Cursos en línea, SPOC, Educación superior, Enfoques para el desarrollo del aprendizaje en línea. 


\section{Introduction}

Informatization processes from the late 1990s to the early 2000s, smoothly changing into digitalization, contributed to the development of technologies, which currently have become a key trend in education. The challenges to upgrade higher education due to its transition to a digital environment have been observed abroad for a decade (Hew \& Cheung, 2014; Kaplan \& Haenlein, 2016; Liyanagunawardena, et al., 2013; Martin, 2012).

Recently, the adoption of a range of programs and priority projects at the level of the government of the Russian Federation is determined by significant changes contributing to the modernization of both the economy as a whole (National Program "Digital Economy of the Russian Federation", 2018) and the education system in particular (Presidential Executive Order No. 204 dated May 7, 2018).

The trend to increase internal costs for the development of the country's digital economy contributes to the demand for competent personnel. Therefore, it is necessary to upgrade education and professional training systems. In addition, it is necessary to introduce digital tools widely for educational activity with their holistic inclusion in the information environment.

The priority project "Modern Digital Educational Environment in the Russian Federation" is particularly focused on the solution of a number of problems. Its aim is "to develop conditions for a systematic improvement of the quality and expanding opportunities for continuous education for all the categories of citizens through the development of the Russian digital educational environment" (MSHE, 2018).

This priority project is based on the active development and implementation of online courses to provide continuous learning opportunities for stakeholders. In this context, the development of technologies contributes to the improvement of the methods and principles of education, which is necessary for keeping pace with the times and for meeting the needs of the society in education (Kornilov, et al., 2019).

Traditional forms of education are being upgraded, e-learning is gaining more and more prevalence and popularity. Distance learning technologies, which are applied both separately and simultaneously, and the learning process itself is gradually turning into digital form. Thus, online learning is developing. However, the pedagogical component of this process is still insufficiently investigated. In this regard, the main problem of the study is determined by the necessity to study the features of the application of modern technologies, online learning technologies in particular, in higher pedagogical education (Moreva, 2018).

At present, the issues of Internet communications promotion and training by means of online technologies and services are becoming especially relevant. The increasing importance of the change imperative, which provides completely new requirements for the modern teachers in terms of the ability to transform in a dynamically changing educational environment, contributes to high competition in the educational services market.

A teacher who works in an analogue mode becomes less competitive in the modern professional community. Moreover, such a teacher loses interest and rating among the students who have been existing and developing in the digital environment for a long period. Additionally, the requirements for students' skills have changed, as it is necessary to be able to organize data resources, collaborate productively, collect, evaluate, and use information.

Objective inevitability of the transformation of the world economy is observed nowadays and is reflected in the Decree of the Government on the approval of the Program "Digital Economy of the Russian Federation" (Program "Digital Economy of the Russian Federation", 
2018). As Moreva (2018) notes, the development of the digital economy nowadays is one of the main challenges facing Russia and other countries of the world community. The rapid development of information and communication technologies (ICT) in terms of a further phase of the scientific and technological revolution has turned them into an organic component of almost all spheres of human life and society.

Despite all the transformations and the existing demand today for the personnel of traditional specialties (lawyers, economists, etc.), there is a shift towards natural science areas, i.e., the development of robotics, artificial intelligence, and neural networks. In this context, a number of hybrid specialties are being formed. Consequently, humanitarian specialties are integrating with technical professions. Each profession becomes partly technological. Technological processes related to the implementation of modern communication technologies and microprocessor technology, are being connected to these professions.

In the Russian economy, this transformation is called "digitalization" or the transition "to digital form" and, according to Moreva (2018), it is characterized by operating costs decrease, elimination of routine operations in production processes and their optimization, labor productivity increase, the development of more flexible relations between the suppliers and customers, competition aggravation, the development of new markets, including foreign ones, and hence the increase in innovation activity and the efficiency of the entities at the micro level, and economic growth and structural development at the macrolevel. In this regard, there is a significant demand for the personnel able to work in emerging circumstances. In addition, it is necessary to improve the education system, which should provide competent personnel for digital economy development.

The described processes indicate a continuous transformation of the labor market, which should be based on the requirements of the digital economy. In order to prepare personnel for the digital economy, it is necessary to upgrade the system of education and professional training, to bring educational programs in compliance with the digital economy needs. Such training is possible due to the widespread introduction of digital tools for educational activity and their integral inclusion in the information environment.

The purpose of the study is to substantiate the conditions and approaches that ensure the development of online learning in higher education basing on domestic and foreign experience.

The objectives of the research are as follows:

- to analyze the prerequisites for online education development;

- to characterize the models and methods of online learning organization;

- to consider the organization of the online learning process using the example of a federal university;

- to identify basic approaches to the development of online education in higher education.

\section{Literature Review}

The authors of the present research followed pedagogical concepts of the implementation of elearning and distance learning technologies in educational process (Bates, 2019; WeindorfSysoeva, 2019; Apykhina, 2014; Moreva, 2018; Barakhsanova et al., 2018). The analysis of conceptual foundations for the implementation of online learning is based on the publications of the foreign authors, namely: Martin, Allen, Seaman, Hew, Cheung, Kaplan, Haenlein, Liyanagunawardena, Adams, Williams, Rovai, Jordan, Tallent-Runnels, Thomas, Lan, Cooper, Ahern, Shaw, and Liu.

Technology development, as well as modification and improvement of teaching methods and principles, contribute to the necessity to upgrade traditional forms of education and introduce 
electronic educational technologies as a powerful tool for solving problems (Kornilov, et al., 2017). These technologies promote opportunities for students' activity, basing on the knowledge gained. They also serve as the basis for the personal and professional application of three types of technologies such as information, activity and organizational (Barakhsanova, et al., 2018).

According to Weindorf-Sysoeva (2019), in modern conditions, the relevance of the implementation of information and communication technologies in the Russian education system is increasing. The number of educational institutions that combine traditional forms of education with distance educational technologies is growing. It is worth highlighting that the majority of modern young people are confident computer users, discover the world through the Internet and competently use the information received from the global Web. However, it should be emphasized that theoretical and methodological foundations for the implementation of online learning as well as the legal regulation of this process are insufficiently developed.

Article 16 of The Federal Law No. 273 "On Education in the Russian Federation" establishes terminological concepts of "e-learning" and "distance learning technologies". Both of these concepts reflect the organization of educational activity, which is implemented through information, information technology, and computer networks both directly and indirectly.

In the context of online courses development, researchers pay attention to the problem of organizing e-learning and online learning at university. It should be noted the reasonableness of some authors' opinion on the research problem in terms of the process integrity. Thus, Vlasova (2014) notes that the application of some technologies and tools in teaching is not a characteristic of integrity and consistency. E-learning is a holistic process. Therefore, it should be a holistic training system. This is also determined by the fact that modern e-learning systems are often called learning management systems (LMS). Modern teachers should be able to carry out this kind of relevant and specific management activity.

The authors of the present research clarify the concepts and descriptions of the principles of online learning organization, the regulatory framework for which has not yet been sufficiently developed.

Thus, Professor Stern (2006) understands online learning as learning via the Internet. In this context, the author points out that "nowadays, online learning is the newest and the most popular form of distance learning. Over the past decade, it has been seriously influencing the higher education; and this tendency is growing".

The website of the University of Victoria (Canada) states that online learning means that courses are taken online, not in class. If your schedule makes it difficult to attend classes, if you prefer studying at your own pace, or if you live far from campus, online learning is a good choice.

All these definitions are fundamentally focused on distance learning, mediated with the Internet. In this regard, it is necessary to define the concept of online learning and online learning technologies, taking into account all their features. Some authors regard online learning as learning at massive open online course (Liyanagunawardena et al., 2013; Martin, 2012; GarcíaPeñalvo et al., 2018). However, the authors of the present research make an attempt to introduce more precise definition, revealing the concept in a broad sense.

In this context, by the term online learning technologies, we understand a set of techniques and processes of interaction between the subjects of educational process to acquire new knowledge by means of Internet technologies in a synchronous and asynchronous mode. 
Online learning is considered in the context of interactive interaction between students and teachers in terms of the learning process at an online course, while providing students with the opportunity to work independently or in groups for mastering the material.

\section{Material and Methods}

The researchers applied the two methods:

(1) theoretical methods, for example, the analysis of scientific, methodological, and educational literature on the issue of the research, classification, generalization and

(2) methods at the empirical level, for example, comparison, description, pedagogical experiment, data processing methods.

As Bates (2019) noted, "Online learning increasingly impacts teaching in the classroom or campus, but what is more important, it contributes to the development of new models or structures for teaching and learning. The transition from classroom teaching to online teaching leads to the changing in the learning environment. Thus, we must develop models where the teaching method is deliberately adapted to the learning environment".

An analysis of a number of publications by a team of authors (Tallent-Runnels, et al., 2006) revealed emphases on online learning, which focuses on the investigation of the learning environment, student performance, student characteristics, and administrative factors.

According to the classification of Kaplan and Haenlein, online learning can be divided by time (Kaplan \& Haenlein, 2016). Students can learn at their own pace in accordance with their schedules (asynchronous distance learning), and concurrently (synchronous distance learning). Tallent-Runnels et al. (2006) explain that "synchronous online courses are organized in such a way that all students are online and communicate simultaneously, while at asynchronous online courses, students can work even if no one else is logged".

Taking into account the degree of the integration of educational process with online technologies and the character of the participants' interaction, experts distinguish traditional, web-supported, blended, and full online learning modes (Allen \& Seaman, 2013).

At present, the use of blended learning is promising, and the distribution of traditional classes combined with e-learning elements provide the possibility to use a variety of means and tools for solving didactic problems. In terms of blended technology, teaching can be applied directly in the classroom, if a teacher interacts with students on an online platform, for example, for feedback, for work evaluation, for exchanging comments on the lesson, and/or for distributing the content used in the classroom. However, the mere use of electronic educational resources in classroom (for example, multimedia presentations) is not considered e-learning (Apykhina, 2014).

In this aspect, under the blended learning technology, the authors of the present research understand "a comprehensive model of interaction between the participants in the educational process, aimed at achieving the planned results, using various degrees of the integration of traditional forms with modern tools for e-learning implementation" (Kornilov \& Sorochinsky, 2015).

Therefore, currently, the most appropriate format is the learning model transformation from traditional form to web-supported, i.e., blended learning. Only after that, it is possible to switch to fully online training. The blended learning concept fully complies with the conditions of student involvement in the digital educational environment, promotes group interaction within online learning process by improving the effectiveness of online platforms and digital environments. Alfred P. Rovai and Hope M. Jordan emphasize that "indeed, the concept of 
blended learning can be a synthesis of these areas, as the learning environment becomes more learning-oriented, with an emphasis on active learning through collaboration and social construction" (Rovai, \& Jordan, 2004). Moreover, the president of Pennsylvania State University Graham B. Spanier considers the convergence of traditional and online learning as the greatest unrecognized trend in higher education (Friedman, 2012).

Massive Open Online Courses (MOOC) are the latest e-learning initiatives that have gained popularity across many universities. MOOC is an open access online course, i.e., without special restrictions on participation, which allows unlimited (mass) participation. Many MOOCs provide interactive elements to encourage interaction between students and between students and teachers. However, the latter is not a defining requirement (Kaplan \& Haenlein, 2016).

Speaking about classification and learning models of MOOCs, it is necessary to mention their origin. Initially, the model of online resource repository emerged and evolved at Massachusetts Institute of Technology (MIT) in the 2000s. It was decided to place all the materials for the disciplines on the network for free access to the students to organize their independent work. There were doubts that students would not attend classes, but the effect was exactly the opposite, i.e., the students' interest increased, they came to the classes prepared, asked questions on the issue, actively participated in discussions.

Subsequently, the model of online resource storage has transferred into massive open online courses, which are still gaining popularity around the world. The following models are distinguished among the massive open online courses: xMOOC, cMOOC, hMOOC, ahMOOC and SPOC:

- xMOOC (extended MOOC) are massive open online courses aiming at scalability;

- cMOOC (connectivist MOOC) are massive open online courses focused on interaction between course participants;

- hMOOC (hybrid MOOC) massive open online courses with the ability to interact with artificial intelligence;

- ahMOOC (combination of hMOOC and the adaptive MOOC) are massive open online courses, divided by the degree of integration of the educational process with online technologies and the character of the interaction of educational process participants;

- SPOCs (Small Private Online Course) are small, private online courses used for the implementation of formal training in an organization.

The emergence of SPOC is determined by the transformation of MOOC into a private local course that serves as a web support. The term was introduced by the professor of the University of California, Berkeley Armando Fox in 2013 to refer to a localized instance of a MOOC. SPOCs are small, closed online courses for the implementation of formal training in organizations. Such courses are developed for small academic groups. In fact, they perform the implementation of the "flipped classroom" learning model, i.e., the necessary materials are delivered to the students in advance, and classroom time is devoted for interaction between the teacher and students in the form collaborative activity. In this regard, SPOCs target particular groups of students who can take the course and agree to interact with others throughout the learning process.

When using SPOC, teacher can define which functions and course content to use. SPOC can contain video lectures, feedback assignments, interactive labs, discussion forums, which can also be used in MOOCs. MOOCs allow teachers to organize their work in classroom in different ways, for example, focusing on project work rather than grading assignments or lectures. SPOC is often associated with "next generation textbooks", allowing educators to decide how to use some parts or the SPOC as a whole (Parr, 2013). 
Online courses development and online education implementation at North-Eastern Federal University (NEFU) began in 2008. The basic platform for the development of a system of electronic and distance learning at M. K. Ammosov North-Eastern Federal University (previous FSAEI of the HVE "North-East Federal University named after M.K. Ammosov") is LMS Moodle, which is focused on the implementation and development of remote interaction of the participants in the educational process.

LMS Moodle is one of the most popular systems in the world belonging to the class of open source and free software. Over the period from 2008 to 2014, more than 1500 electronic courses were filled in the electronic environment of the university. The materials were mainly focused on web support for students, educational materials, and online testing.

Today, the system contains educational materials for more than 3000 disciplines, which is $30.16 \%$ of the total number of disciplines being implemented. For the period from 2015 to 2019 , there is a positive trend in the use of materials from these electronic courses by NEFU employees. Therefore, the number of disciplines for which educational and methodological materials were posted has been constantly increasing since 2015, and the number of educational programs with the implementation of e-learning and distance learning technologies has increased up to $30.16 \%$.

In 2018, NEFU made an attempt to develop the first massive open online courses on the deployed Open edX platform. The first MOOCs were introduced by the Department of Philosophy and the Faculty of History:

- "Introduction to Biochemistry";

- "The main stages of Classical Philosophy";

- "The main stages of Modern Philosophy";

- "The History of Yakutia: from Ancient Times to the Middle Ages".

In 2019, the candidate of economic sciences, associate professor of the Financial and Economic Institute Romanova introduced an online course "Statistics", which was indexed on the portal "Modern Digital Educational Environment in the Russian Federation" (online.edu.ru). This online course is targeted for the students of different areas, and is the basis for the subsequent study of industry statistics such as demographic statistics, education statistics, health statistics, legal statistics, etc.

It should be noted that this online course is posted on the online education portal of the Povolzhsky Regional Center for Education and Training (Volgatech), which is based on LMS Moodle, which confirms the relevance of this LMS.

The authors of the study on the electronic and distance learning system of NEFU (EDLS NEFU) present more than a dozen different online courses for teachers of vocational training (code 44.03.04) in the field of "Informatics and Computer Engineering".

Each online course was based on a number of LMS Moodle elements ("Discrete Lecture", "Seminar", "Poll', "Webpage", "Test", etc.) and has an extensive content of various didactic materials in PDF, PPTX, SWF formats, etc.

The most informative are courses on computer communications and networks, multimedia technologies, and computer graphics

According to the presented models, all the courses under consideration are SPOCs for small student groups. The access to online courses is open only for registered users mastering Bachelor's or Master's programs at NEFU. 
The filling of these courses has been conducted since 2014 with additions and upgrades. The specificity of teaching in the field of "Informatics and Computer Engineering" requires annual updating and upgrading due to continuous changes in the field of information technology.

The relevance of this study, which is focused on the implementation of online education at university in the context of digitalization, is confirmed by the increasing number of users' requests to the materials of the online courses.

One of the progressive online courses is the course for the discipline "Computer communications and networks". It shows the annual growth in the number of students' requests for the educational materials from 451 requests in 2015 to 2183 requests in 2019 (Kornilov \& Gosudarev, 2019).

\section{Results}

In recent years, various approaches have been applied to promote the implementation of online learning technologies by the NEFU employees.

One of the managerial tasks set by the university authorities for the academic staff of NEFU for the coming years is to transfer $20 \%$ of the classroom teaching load to online courses. This type of mechanism can be attributed to administrative, which is based on the managerial solutions that ensure the implementation of managerial tasks.

To solve this problem, it is necessary to provide the conditions, which will contribute to the development of a sufficient number of high-quality online courses. Therefore, bonus system for teachers who actively use electronic courses based on the EDLS NEFU (yagu.s-vfu.ru) was introduced in NEFU during the period from 2016 to 2017. In this context, students' activity was considered. The use of educational and methodological materials from the teacher's personal account in the EDLS NEFU is confirmed by an automatically generated certificate. The total number of students' visits to each electronic course of an individual teacher was registered.

In 2019, in order to improve professional competencies of the academic staff of NEFU in the field of online training, as well as to promote the use of online courses in training, one of the authors of the present research organized advanced training course "Online Learning Technologies in the Context of Digital Educational Environment". The course provided knowledge on theoretical and methodological foundations of online learning, educational applications implementation, services and their use in professional activities in terms of online learning implementation in a digital educational environment. The course was for 72 hours, part of the classes was planned to be held by means of distance learning technologies.

Introduced training course allows us:

- to familiarize the attendees with modern technologies of online education, cloud services and their application in the professional activity;

- to study a number of educational applications (including mobile) and services, learn how to create educational content using online technologies;

- to analyze the possibilities of webinars as a form of educational activities;

- to introduce the basic rules of safe work and the threats spread by the Internet;

- to organize scientific support for online training and scientific counselling on the topic.

The course involved 40 academic and auxiliary educational staff of NEFU. In addition, an online digital educational platform was designed on LMS Moodle version 2.7. This platform was deployed to the server environment of NEFU Pedagogical Institute, which is part of NEFU corporate network. 
This allowed us to solve several problems:

- to develop a platform for students' training (registration, placement of training materials, students' communication and interaction);

- to provide the attendees with an access to training courses (sandbox) to develop practical skills for working with LMS Moodle;

- to receive operational information from the event log about each attendee's activity, his or her success and the timeliness of the course materials mastery;

- to have a feedback from the attendee after each module accomplishment (comprehensive assessment).

The author's advanced training course is devoted to online learning technologies, the use of cloud services in professional activities, educational applications and services, webinars, as well as Internet security issues.

Each module contains informational, educational, testing, and assessment materials presented in various forms such as text lectures, interactive (discrete) lectures, presentations, video lectures, questionnaires, SCORM packages, assignments, etc. Each module contains from six to 18 hours of lectures, practice, supervision and independent work.

To help teachers to improve their competence in the development of online courses on the Moodle platform, the author of this study designed a computer program "Development of Electronic Educational Resources on the Moodle Platform" in the form of a single-user electronic educational resource. The Program was registered in the Register of Computers Programs of the Federal Service for Intellectual Property dated December 2018.

The program reveals the elements for the design of electronic content for online courses, methods of creating various electronic educational resources based on the Moodle. The main goal is to describe the procedures for teachers and students in the framework of their interaction in the LMS Moodle. The program describes and illustrates the steps for implementing various elements of the course and provides detailed instructions on their application. This program will help in creating an electronic educational resource from scratch to complete introduction in the educational process.

Thus, the last group of approaches, described in detail above, can be attributed to the category of educational ones, which allow solving the assigned tasks through education.

According to the analysis conducted, there are three main approaches to the development of online learning in higher education:

- administrative, i.e., making managerial decisions by the university administration;

- stimulating, i.e., the use of methods of external motivation, including material one;

- educational, i.e., development of the academic staff's competencies by means of advanced professional education.

\section{Discussion}

Assessing the situation in Russia on the implementation of online learning and the strategy of some universities in particular, the authors emphasize that in the near future, each university will have to reorganize its educational process basing on the provision of educational services online. Leading Russian universities have already started the transition of all lectures to the online format, believing that it will increase students' involvement, relieve professors, and improve the quality of university education. It is worth highlighting that lectures will be replaced by online courses gradually during several years. Such a transition to the release of classroom load will allow teachers to have more time for research work. 
The results of the study allow us to identify the following theoretical premises and directions for future research in the sphere of online learning in higher education:

- maintenance of the lecture cycle transfer to online format; this will contribute to the development of new courses; the popularity of existing online courses from leading universities will grow;

- support and development of SPOC courses, focusing on intensive online interaction between students and teachers, i.e., a partial transition from massive open online courses to small private online courses;

- search for new proper models for online learning implementation, including those that eliminate the drawbacks of existing ones, i.e., the use of a complementary model of online learning, replacement model of online learning, new hybrid models, and artificial intelligence, etc.;

- development of new approaches to online education in terms of higher education (including the approaches that make it possible to actively involve leading teachers for sharing the latest experience in training highly qualified graduates);

- modernization of online learning methods, contributing to the involvement and holding of the students' attention, remote support of the students' independent work, upgrade of assessment systems, as well as some applied methods and techniques.

The obtained results contribute to the improvement of the existing approaches, but also to the search for new ways to support and develop online education in higher education.

\section{Conclusion}

The authors of the present research have analyzed theoretical characteristics of the online education implementation, have revealed the methods of its organization, and have determined the modern requirements for teaching in higher education. In this context, the models, methods and technologies of online education development, which are successfully used for teachers' training in higher education, have been characterized.

According to the results of the analysis of regulatory documents and research literature, the prerequisites for the development of online education in the Russian Federation, which are determined by the necessity to transform the educational environment and the transition to digital form, have been considered. The basic priorities for the future development of online education have been determined in accordance with the recommendations from the national programs and priority projects.

The authors have introduced the classification of online learning by time (synchronous, asynchronous), have considered the classification according to the degree of educational process integration with online technologies and the characteristics of the participants' interaction (web support, blended learning, fully online learning). Additionally, it was conducted a review of online course models by the format of interaction between the participants (model of online repository courses, xMOOC, cMOOC, hMOOC, ahMOOC, and SPOC).

In the course of the study, the main approaches to the development of online learning at NEFU have been identified, namely, the training of the academic staff at profile advanced training 
courses, which contribute to the development of professional competencies in the field of online education implementation. For this purpose, the author's advanced training course "Online Learning Technologies in the Context of Digital Educational Environment" was organized involving 40 attendees. The training was conducted by means of the online digital educational platform designed on LMS Moodle, which made it possible to solve several problems:

- to develop a platform for the attendees' training (registration, placement of training materials, students' communication and interaction);

- provide the attendees with an access to training courses (sandbox) to develop practical skills for working with LMS Moodle;

- receive operational information from the event log about each attendee activity, his or her success and the timeliness of the course materials mastery;

- to have a feedback from the attendees after each module accomplishment (comprehensive assessment).

It is estimated, that the implementation of the approaches to the development of online learning in higher education, identified in this study, will contribute to the quantitative and qualitative development of new online courses, designed for transferring the share of the classroom load into the digital environment, involving students into interaction in a new digital environment.

\section{References}

Allen, E., \& Seaman, J. (2013). Changing Course: Ten Years of Tracking Online Education in the United States. Babson Survey Research Group and Quahog Research Group, LLC.

Apykhina, I.E. (2014). Information material on e-learning of the Ministry of Education and Science of the Russian http://ido.tsu.ru/normdocs/elearning/PS\%2019.05.2014\%20-\%20Material\%20

Minobrnauki.pdf (Access Date: 06.04.2019).

Barakhsanova, E.A., Varlamova, V.A., Vlasova E.Z., Nikitina, E.V., Prokopyev, M.S., Myreeva, A.N. (2018). Vocational training of school teachers in Yakutia's universities through the principle of regionalization (case study of the methodology of teaching natural science to prospective teachers). Revista Espacios, 39(20), 35-44.

Bates, A.W. (2019). Teaching in a Digital Age - Second Edition. Vancouver, B.C. Tony Bates Associates Ltd. https://pressbooks.bccampus.ca/teachinginadigitalagev2/

Friedman, T.L. (2012). Come the Revolution. New York Times, https://www.nytimes.com/2012/05/16/opinion/friedman-come-the-revolution.html

García-Peñalvo, F.J., Fidalgo-Blanco, Á. \& Sein-Echaluce, M.L. (2018). An adaptive hybrid MOOC model: Disrupting the MOOC concept in higher education. Telematics and Informatics. 35(4). pp. 1018-1030. doi:10.1016/j.tele.2017.09.012

Hew, K. F., \& Cheung, W. S. (2014). Students' and instructors' use of massive open online courses (MOOCs): Motivations and challenges. Educational Research Review. 12, 45-58. doi:10.1016/j.edurev.2014.05.001

Kaplan, A. M., \& Haenlein, M. (2016). Higher education and the digital revolution: About MOOCs, SPOCs, social media, and the cookie monster. Business Horizons. 59(4), 441450. doi:10.1016/j.bushor.2016.03.008

Kornilov, I.V., \& Gosudarev, I.B. (2019). Experience in developing online courses and organizing online learning in higher education. Modern Problems of Science and Education, 5, 60.

Kornilov, I.V., \& Sorochinsky, M.A. (2015). Implementation of blended learning technology as an effective interaction of the parties in the educational process. Proceedings of the online international scientific and practical conference "E-learning at university and at school". St. Petersburg. Asterion. pp. 150-154 
Kornilov, I.V., Danilov, D.A., Kornilova, A.G., Kovtun, T.I. Methodical approaches to implementation of electronic educational technologies in professional academic teacher training (2017). Man in India, 97 (15), 441-460. https://www.scopus.com/inward/record.uri?eid=2-s2.085027307136\&partnerID=40\&md5=a7cbf961c655021751112e65dbc828ab

Kornilov, I.V., Nikolayeva, A.D., Golikov, A.I., Gosudarev, I.B. (2019). Education system features in the Arctic Economic Zone of the Republic of Sakha (Yakutia) of the Russian Federation: An expert assessment. Revista Espacios. 40 (9). pp. 1-20. https://www.scopus.com/inward/record.uri?eid=2-s2.085063509216\&partnerID=40\&md5=87547e0b69a9b3588a6c341d863534fc

Liyanagunawardena, T. R., Adams, A. A., \& Williams, S. A. (2013). MOOCs: A systematic study of the published literature 2008-2012. International Review of Research in Open and Distance Learning, 14(3), 202-227.

Martin, F. G. (2012). Will massive open online courses change how we teach? Communications of the ACM, 55(8), 26-28. doi:10.1145/2240236.2240246

Moreva, E.L. (2018). Problems of the transition to a digital economy: foreign recipes and Russian alter-natives. State Administration. Electronic Bulletin, 70, 344-359.

MSHE (2018). Priority project "Modern Digital Educational Environment in the Russian Federation". Official website of the Ministry of Science and Higher Education. https:// minobrnauki.rf/proektyi/ sovremennaya-tsifrovaya-obrazovatelnaya-sreda.

National Program "Digital Economy of the Russian Federation". (2018). (Digital resource). RF Government website. http://static.government.ru/media/files/9gFM4FHj4PsB79I5v7yLVuPgu4bvR7M0.pdf

Parr, C. (2013). MOOCs? They're a cracking good idea. https://www.timeshighereducation.com/news/moocs-theyre-a-cracking-goodidea/2005078.article

Presidential Executive Order No. 204 dated May 7, 2018 "On National Goals and Strategic Objectives of the Russian Federation through to 2024". Official website of the President of Russia. http://static.kremlin.ru/media/acts/files/ 0001201805070038.pdf (Access date: 02.04.2019).

Rovai, A. P., \& Jordan, H. M. (2004). Blended learning and sense of community: A comparative analysis with traditional and fully online graduate courses. International Review of Research in Open and Distance Learning, 5(2). https://doi.org/10.19173/irrodl.v5i2.192.

Stern, J. (2006). Introduction to Online Teaching and Learning. West Los Angeles College. http://www.wlac.edu/online/documents/otl.pdf

Tallent-Runnels, M.K., Thomas, J.A., Lan, W.Y., Cooper, S., Ahern, T.C., Shaw, S.M., \& Liu, X. (2006). Teaching courses online: A review of the research. Review of Educational Research, 76(1), 93-135. doi:10.3102/00346543076001093

Vlasova, E.Z. (2014). E-learning in the modern university: challenges, prospects and experience. Universum: Bulletin of the Herzen University, 1, 43-49.

Weindorf-Sysoeva, M.E., Gryaznova, T.S., Shitova, V.A. (2017). Distance Learning Technique: Textbook. Moscow: Yurayt. 